\title{
PATTERNING IN RECENT RADIOCARBON DATES FROM SOUTHERN AFRICA AS A REFLECTION OF PREHISTORIC SETTLEMENT AND INTERACTION
}

BY JOHN PARKINGTON AND MARTIN HALL

THIs article is the latest in a series designed to review for Fournal readers the impact of newly acquired dates on the writing of southern African prehistory. ${ }^{1}$ As the number of dates has increased, and as the integration of dates into archaeological research programmes has progressed, it has become necessary to survey new dates more regionally and assess them more contextually. Thus previous syntheses in this series have moved away from annotated sets of dates to more thematic summaries of recent research as it is affected by a growing ability to date specific patterns of behaviour.

We have followed the precedent of Hall and Vogel $^{2}$ in avoiding as far as possible both modern political units of space and what they called 'transregional cultural categories' of time such as Later Stone Age and Early Iron Age. The reason for this is simply that both sets of terms may be quite unsuitable formats for understanding prehistoric behaviour and may encourage us to compartmentalize what must have been integrated and complex interactions between people with different technologies. At the same time, we have found it difficult to review new radiocarbon dates strictly by environmental zones, for the problems currently prominent in southern African archaeological research often transgress such regional boundaries. Consequently, the text of this review assesses the contribution that new dates have made to research problems, while the map (p. i 8 ) gives the location of sites in relation to environmental zones.

Colleagues in the Southern African Association of Archaeologists kindly responded to a circular by sending lists of recently published dates, and additional readings were obtained from the journal Radiocarbon ${ }^{3}$ and elsewhere. Geographically, the dates come from those parts of southern Africa south of the Kunene, Okavango and Zambezi rivers, and they are listed in the Appendix by laboratory and site name. Radiocarbon determinations presented here are based on the original Libby half-life of 5,568 years and are uncalibrated; they are expressed in terms of years b.c. and a.d.

1 Previous reviews of southern African radiocarbon dates which have appeared in this Journal include those by Martin Hall and J. C. Vogel (XXI, iv, I 980, 43I-55), Tim Maggs (xviII, ii, I977, I6I-9I), R. C. Soper (xv, ii, I974, I75-92), J. E. G. Sutton (xIII, i, I 972 , I-24) and D. W. Phillipson (XI, I, I 970, I-I 5).

2 Martin Hall and J. C. Vogel, 'Some recent radiocarbon dates from southern Africa', F. Afr. Hist., xxi, iv (1980), 43 I.

3 J. C. Freundlich, H. Schwabedissen and W. E. Wendt, 'Köln radiocarbon measurements II', Radiocarbon, xxII, i (I980), 68-8I. J. C. Vogel and Ebbie Visser, 'Pretoria radiocarbon dates II', Radiocarbon, XXIII, i (I98I), 43-80. 
THE KALAHARI BASIN

Field research by a number of archaeologists in the western Kalahari Basin - the sandveld - has shown that sites from the seventh to the nineteenth centuries A.D. may contain artefacts traditionally classed as 'Stone Age' alongside those thought of as 'Iron Age', thus well illustrating the problems in applying the traditional system of two 'ages' in southern African prehistory. Recently dated sites in this category range from the seventhcentury Matlapaneng (I-I2.80I) to the nineteenth-century occupation of Xgi (SI-4098), and include Nxai Nxai (BETA-3970), Serondella (I-I 2.799), Chobe (I-I 2.800), Hippo Tooth (I-I2.I65), Society (I-I I.4I I), Outpost I (WITS-836), Serondella (upper level) (I-I2.798), Depression Cave (I-I I .824) and Kwebe Hills (I-I 2 . I63). ${ }^{4}$

By contrast, the sequence in the eastern part of the Kalahari Basin illustrates, within the same time range, the rapid establishment of a hierarchy of settlements with some very large (approx. I00,000 $\mathrm{m}^{2}$ ) localities and 'incontestable evidence that very large herds were maintained for very long periods of time at these sites'. ${ }^{5}$ Settlements from which radiocarbon dates are available include Toutswe (I-I I.4I2), Bisoli (I-I2.708, WITS-I099), Taukome (O-I I .409), Thatswane (I-I I .407, I - I I . 4 I O, I - I I . 4 I 4, I - I I . 4 I 5) and Maiphetwane (PTA-2526), constituting Denbow's Toutswe Tradition, ${ }^{6}$ and Moritsane (I-I I .823) and Broadhurst (WITS-837) from further to the south. ${ }^{7}$

Denbow and Wilmsen ${ }^{8}$ suggest that some greater understanding of the interrelations between hunting and gathering and pastoralism will come from the adoption of a spatial and ecological approach to the archaeological residues. But the archaeology of the Kalahari Basin also serves to underline the relative poverty of archaeological concepts and devices for understanding the kinds of interactions presumably reflected in these admixtures. When are we looking at transitional economies, when are we seeing the results of exchange relationships, when may we suspect class distinctions or clientship and when are we merely dealing with a poorly resolved archaeological sequence?

One conceptual device that does seem appropriate to the Kalahari in prehistory is what Alexander ${ }^{9}$ refers to as a static frontier, a relatively stable but highly permeable interface between regions where different kinds of subsistence are deemed appropriate.

${ }^{4}$ J. R. Denbow and E. N. Wilmsen, 'Iron Age pastoralist settlements in Botswana', S. Afr. F. Sci., xxix (1983), 406.

${ }^{5}$ E. N. Wilmsen, 'The impact of land tenure policies on the future of the San' (paper presented at the International Symposium on African Hunter Gatherers, Cologne, 1985), 2.

${ }^{6}$ J. R. Denbow, 'Cows and Kings: a spatial and economic analysis of a hierarchical Early Iron Age settlement system in Eastern Botswana' in M. Hall, G. Avery, D. M. Avery, M. L. Wilson and A. J. B. Humphreys (eds.), Frontiers: Southern African Archaeology Today (British Archaeological Reports, International Series, 207) (Oxford, I 984), 24-39.

' Denbow and Wilmsen, 'Iron Age pastoralist settlements', 406.

${ }^{8}$ Ibid.

9 J. Alexander, 'Early frontiers in southern Africa', in Hall et al., Frontiers, I 2. 
All of the desert area, except the far west, where no reconnaissance has yet been done, that has heretofore been thought to have been the exclusive preserve of San foragers until the mid-nineteenth century or later, has yielded this suite of Early Iron Age pastoralist material. Thus contact between foragers and food producers has a very long history and has not been limited to the past two centuries. ${ }^{10}$

The demonstration of long-term interaction between hunters and agriculturalists or pastoralists prompts the question whether San were ever in the more arid parts of the Kalahari prior to the approach of pastoralists. Could it be that the penetration of pastoralists, or agriculturalists, enabled (or compelled) hunters to relocate and, in effect, turn themselves into a professional group with quite specific exchange relations with nearby herders or farmers? It is not unlikely that the 'marginal' areas in which hunting groups have recently been documented were improved over the past two millennia by their proximity to incoming peoples with different technologies, different needs and different land-use patterns. The combination of a dense network of radiocarbon dates and reliable, fine-grained palaeoenvironmental reconstructions, neither of which yet exists, will do much to answer this question.

\section{GHAAP AND GARIEP}

A second cluster of recent dates comes from the southern margins of the Kalahari, some from the Ghaap escarpment, and the hills to the east; others from the middle reaches of the Orange or Gariep river. ${ }^{11}$ Most of these sites lie close to what must in late prehistoric times have been the boundary between the savannah of the Kalahari thornveld to the north and the grassland of the highveld or the shrubland of the Karoo to the south. This suite of dates has relevance both to the hypothesis that there was a mid-Holocene depopulation of the arid Cape interior, and to the understanding of the pattern of penetration of pastoralists south of the Gariep in the last two millennia and subsequent intergroup relationships.

Janette Deacon ${ }^{12}$ has suggested that it might be possible to track the changing density of human settlement over the varied topography of Southern Africa by noting the temporal and spatial patterning in radiocarbon dates. Effectively, this would allow archaeologists to document the ebb and flow of population about the prehistoric landscape as changes in environment, technology and organization altered the relative attractiveness of different regions.

Deacon's original model dealt specifically with an early Holocene dearth of radiocarbon dates in the Cape interior between the southern fringes of the Kalahari and the northern edge of the Cape Fold Belt. Her suggestion was that in the millennia between about 9,500 and 4,500 years ago this area was even more arid than it is today, and that human population densities were so low there as to have left virtually no datable trace in the archaeological record. The most persuasive evidence for this was the number of dates

10 Wilmsen, 'Impact of land tenure policies', 2.

11 A. J. B. Humphreys and A. I. Thackeray, Ghaap and Gariep (South African Archaeological Society Monograph Series, 2) (Cape Town, r983).

$12 \mathrm{~J}$. Deacon, 'Patterning in the radio-carbon dates for the Wilton/Smithfield complex in southern Africa', S. Afr. Archaeol. Bull., xxix (r 974), 3-I8. 
obtained by Sampson ${ }^{13}$ in the middle Orange river valley and by Humphreys ${ }^{14}$ along the Ghaap escarpment, none of which fell into those early Holocene millennia. H. J. Deacon's ${ }^{15}$ excavations at Highlands seemed also to support the notion of Holocene people expanding out of the Cape Fold Belt into the Karoo interior only after 4,000 years ago.

But the dates listed here from Wonderwerk ${ }^{16}$ and Little Witkrans, ${ }^{17}$ and that reported earlier from Voigtspos, ${ }^{18}$ demand some modification of Deacon's original hypothesis. If we distinguish the Ghaap escarpment sites from those $300 \mathrm{~km}$ to the south in the middle Orange river catchment area, we see clearly that, whilst some settlement through the Holocene is documented in the former, it is not yet visible in the latter. There do seem to be sites in the present-day Karoo, such as Highlands, ${ }^{19}$ Zaayfontein, ${ }^{20}$ Blydefontein ${ }^{21}$ and Riversmead, ${ }^{22}$ where regular occupation only begins after 4,000 years ago.

Van Zinderen Bakker's ${ }^{23}$ reconstruction of rainfall patterns in the early Holocene suggests 'a southward penetration of summer rain of tropical origin' about the latitude of Wonderwerk. Seemingly supporting this is the summary of palaeoenvironmental information from this site which is taken to imply the spread of woodland savannah into the area between 9,000 and 5,000 years ago. ${ }^{24}$ Clearly there is a chance that palaeoclimatic changes affected the Ghaap and Gariep areas differently, leading to different settlement trajectories. It is not unlikely that Janette Deacon's original explanation fits the Gariep or Orange river sites, but should not be taken to include the better-watered region to the north.

Secondly, the large sample of sheep and cattle bones dated to more than I, IOo years ago at Blinkklipkop ${ }^{25}$ and Doornfontein ${ }^{26}$ are extremely significant in pushing back the appearance of pastoralism south of the Gariep well beyond previous estimates. ${ }^{27}$ Indeed, if the dates reported here from

13 C. G. Sampson, 'The Stone Age industries of the Orange River scheme and South Africa', Memoirs of the National Museum (Bloemfontein), vi (1982), I-288.

14 A. J. B. Humphreys, "The Holocene sequence in the northern Cape and its position in the prehistory of South Africa' (Ph.D. thesis, University of Cape Town, 1979).

${ }^{15}$ H. J. Deacon, Where Hunters Gathered (South African Archaeological Society Monograph Series, I) (Cape Town, I 976).

16 P'TA-2 I 40, P'TA-254 I, PTA-2 542, PTA-2543, PTA-2544, PTA-2 545, PTA-2546, PTA-2723, PTA-2727, PTA-2728, PTA-2729, PTA-2779, PTA-2785, PTA-2790, PTA-2797, PTA-2798, PTA-2852, SI-2030. Humphreys and Thackeray, Ghaap and Gariep, $45^{-6 .}$

17 PTA-2447, P'TA-2448, P'TA-2490; ibid., 175.

18 Hall and Vogel, 'Recent radiocarbon dates'.

19 Deacon, Where Hunters Gathered, 222.

20 C. G. Sampson, Stone Age Archaeology of Southern Africa (New York, I 974), 33 I.

21 Ibid.

22 Ibid.

${ }^{23}$ E. M. van Zinderen Bakker, 'Comparison of Late Quaternary climatic evolutions in the Sahara and the Namib-Kalahari region', Palaeoecology of Africa, XII ( I980), 390.

24 Humphreys and Thackeray, Ghaap and Gariep, 94-5.

25 P'TA-2835, 2840: ibid., 103.

26 PTA-1 86 : ibid.

27 Previous estimates of about 400 years before the present appear in Humphreys, 'The Holocene sequence', and in R. G. Klein, 'Palaeoenvironmental and cultural implications of late Holocene archaeological faunas from the Orange Free State and north-central Cape Province, South Africa', S. Afr. Archaeol. Bull., xxxiv (1979), 34-49. 
Little Witkrans, ${ }^{28}$ Limerock $^{29}$ and Dikbosch ${ }^{30}$ are reliably associated with ceramics, it is possible that pastoralist penetration is as early in the Ghaap plateau as it is elsewhere in the Cape.

In turn, these new dates have a significance for understanding the origins of pastoralism at a sub-continental scale, as there has been considerable debate in the literature as to the route by which ceramics and domestic stock reached the southern parts of the subcontinent. On the one hand, it has been suggested that pastoralists first moved westwards and then southwards along the Cape coast, thus implying that there was no early penetration of the Ghaap plateau. ${ }^{31}$ In contrast, the route suggested by Elphick would bring incoming pastoralists through the Ghaap/middle Gariep area before they reached the southern and western Cape. ${ }^{32}$ As yet, the antiquity of the pattern in the Ghaap region is not as well established as that in the Cape Fold Belt or Namibia, although some suggest that the introduction of sheep into the Kuruman hills and Ghaap plateau may be as early as 3000 B.P. ${ }^{33}$

Regardless of the resolution of this issue, Beaumont and Vogel ${ }^{34}$ have nicely illustrated, with a suite of dates included in this review, that there are a number of interesting and contrasting contexts in which ceramics appear in the regions of the Vaal/Orange confluence. Particularly in the past halfmillennium, this has been an area of great population diversity and one presumably marked by complex intergroup relations. These relations have not yet been investigated in any detail, but the resolution of their complex archaeological record will require a research design more subtle than simply attempting to trace back historically known groups into the prehistoric period. Sites which have been dated recently, and which will be important in the emergence of patterning, are Bitterputs $\mathrm{I},{ }^{35}$ Douglas, ${ }^{36}$ Khartoum $\mathrm{I},{ }^{37}$ Kimberley, ${ }^{38}$ OFD $1,{ }^{39}$ Suurwater, ${ }^{40}$ Waterval West $3{ }^{41}$ Biessiesfontein, ${ }^{42}$

${ }^{28}$ Humphreys and Thackeray, Ghaap and Gariep, 175.

29 PTA-I 62 I, I 759, 2095: ibid., 205.

30 PTA-34I 3, 34 I2: ibid., I 59.

${ }^{31}$ G. W. Stow, The Native Races of South Africa (London, 1905; reprinted New Haven, I 977); H. J. Deacon, J. Deacon, M. Brooker and M. L. Wilson, 'The evidence for herding at Boomplaas Cave in the southern Cape, South Africa', S. Afr. Archaeol. Bull., XxxiII (1978), 39-65; P. T. Robertshaw, 'The origin of pastoralism in the Cape', S. Afr. Hist. F., x ( 1978), г г 7-1 33 .

${ }^{32}$ R. Elphick, Khoikhoi and the Founding of White South Africa (Johannesburg, 1985). This interpretation has been supported, on linguistic grounds, by C. Ehret, 'The first spread of food production in southern Africa', in C. Ehret and M. Posnansky (eds.), The Archaeological and Linguistic Reconstruction of African history (Berkeley, I 982), I 58-81.

${ }^{33}$ P. B. Beaumont, 'On the origins of Hottentot culture in southern Africa', $S . A f r$. Archaeol. Soc. Nezwsletter, III, i ( 1980), 2-3.

${ }^{34}$ P. B. Beaumont and J. C. Vogel, 'Spatial patterning of the ceramic Later Stone Age in the northern Cape Province, South Africa' in Hall et al. (eds.), Frontiers, 80-95.

${ }_{35}$ PTA-3359: I. Rudner and J. Rudner, 'Wilton sand-dune sites in north-western Cape and South West Africa', S. Afr. Archaeol. Bull., XIV (1959), I42-5; Beaumont and Vogel, 'Spatial patterning', 94.

${ }^{36}$ PTA-3088: Beaumont and Vogel, 'Spatial patterning', 94.

37 PTA-3093: ibid. ${ }_{38}$ PTA-3094: ibid., 95. ${ }_{39}$ PTA-964: ibid., 94.

40 PTA-3357: Rudner and Rudner, 'Wilton sand-dune sites'; Beaumont and Vogel, 'Spatial patterning', 92.

41 PTA-3 I09: Beaumont and Vogel, 'Spatial patterning', 94.

42 PTA-34I 7 : ibid., 93. 
Blinkklipkop, ${ }^{43}$ Dithakong, ${ }^{44}$ Doornfontein, ${ }^{45}$ Equus Cave, ${ }^{46}$ Glen Elliott Shelter, ${ }^{47}$ Limerock I Shelter ${ }^{48}$, Limerock 2 Shelter, ${ }^{49}$ Norlim $5^{50}$ and Voigtspost $\mathrm{O}^{51}$.

\section{N A M I B I A}

More than one-third of the new dates listed in the Appendix come from the western peripheral highlands and associated coastal forelands and coasts. This is partly because the bulk of the radiocarbon dates obtained by Wendt ${ }^{52}$ as part of his survey of southern Namibia have recently been published, but it also reflects a high level of activity in general by Windhoek-based archaeologists.

A prominent feature of the accumulated pattern of Namibian dates, noted already by Wendt ${ }^{53}$ and Vogel and Visser ${ }^{54}$, is that almost all of the caves or small shelters excavated show highly discontinuous sequences in which widely separated radiocarbon ages are found juxtaposed stratigraphically. This can be seen clearly in the diagrammatic Apollo XI sequence illustrated in the Köln radiocarbon list ${ }^{55}$, but is just as characteristic of Mirabib, ${ }^{56}$ Pockenbank, ${ }^{57}$ Namtib, ${ }^{58}$ Maguams, ${ }^{59}$ Aar $2,{ }^{60}$ Haalenberg $^{61}$ and Cha-ré. ${ }^{62}$

One effect of this is to render suspicious some 'associations' between dated charcoal and other excavated items of interest such as ceramics, domestic

43 PTA-2833, 284I, 34 I 9: A. I. Thackeray, J. F. Thackeray and P. B. Beaumont, 'Excavations at the Blinkklipkop specularite mine near Postmasburg, northern Cape', $S$. Afr. Archaeol. Bull., xxxviI (1983), I 7-25.

44 PTA-3444, 3462, 3466: Beaumont and Vogel, 'Spatial patterning', 95.

45 P'TA-ı 86, 3089: ibid., 92.

46 PTA-2452: ibid., 9 I.

47 PTA-340I: Humphreys, 'The Holocene sequence'.

48 P'TA-I $62 \mathrm{I}$ : ibid.

49 PTA-I 759, 2095: ibid.

50 PTA-3367, 342 I : Beaumont and Vogel, 'Spatial patterning', 95.

51 PTA-1 483 : ibid., 93.

52 Freundlich, Schwabedissen and Wendt, 'Köln radiocarbon measurements'; Vogel and Visser, 'Pretoria radiocarbon dates'. See also W. E. Wendt, 'Preliminary report on an archaeological research programme in South West Africa', Cimbebasia B, II (I972), $\mathbf{I}-6 \mathbf{I}$.

53 W. E. Wendt, 'Ein Rekonstruktionsversuch der Besiedlungsgeschichte des westlichen Gross-Namalandes seit dem i 5. Jahrhundert', F. S. W. Afr. Sci. Soc., xxıx ( 975 ), 23-56.

54 Vogel and Visser, 'Pretoria radiocarbon dates', 44.

55 Freundlich, Schwabedissen and Wendt, 'Köln radiocarbon measurements', 70.

56 PTA-IOI I, IоI 2, I I 13, I 347, I 348, I 536: Vogel and Visser, 'Pretoria radiocarbon dates', 56.

57 KN-I . 624, P'TA-I 202: Freundlich, Schwabedissen and Wendt, 'Köln radiocarbon measurements', 74; Vogel and Visser, 'Pretoria radiocarbon dates', 48.

58 KN-2 I 42, KN-2 I 43, PTA-I 1 85, P'TA-I I 86: Freundlich, Schwabedissen and Wendt, 'Köln radiocarbon measurements', 76; Vogel and Visser, 'Pretoria radiocarbon dates', $5 \mathbf{I}$.

59 KN-1.631, KN-1.632, KN-1.633, PTA-2662: Freundlich, Schwabedissen and Wendt, 'Köln radiocarbon measurements', 77; Vogel and Visser, 'Pretoria radiocarbon dates', 52.

60 P'TA-1046, I 55, I 75 I : Vogel and Visser, 'Pretoria radiocarbon dates', 49.

61 P'TA-1 927, 2650: ibid., 50.

62 P'TA-2075, 2077, 2082: ibid., 55. 
stock and painted slabs. The way strata are crosscut by later levels indicates clearly that prehistoric people were involved in substantial earthmoving, presumably to make life more comfortable in the shelters, and that excavations in non-stratigraphic spits are likely to associate erroneously items of very different ages. This would seem the best interpretation of dates between 2000 and 3000 B.P., and even two over 7000 B.P. ${ }^{63}$ with 'associated' ceramics.

Beyond this kind of danger, however, the sequences do seem to show considerable geographic patterning. We refer here to the observation that many sites in southern and central Namibia show ceramic horizons preceded by substantial periods of non-deposition. A number of sites, all of those with mid-Holocene dates in fact, ${ }^{64}$ have dates of 5000 to 7000 B.P. immediately below the surface or below levels of sub-recent age. There is thus a ubiquitous 4,000-5,000 year gap in excavated sequences. Whilst a more detailed consideration of these stratigraphies may be out of place here, it is fair to say that cave occupation in the southern part of the western highlands was relatively common in the post-glacial climatic optimum between 9,000 and 6,000 years ago, but almost non-existent thereafter until the appearance of pastoralism. Even then, dates are rare until the last 600 years or so, when many shelters show occupation.

There is, interestingly, a series of sites which show a different pattern, and these are without exception at the northern limits of those just described and located in the inselbergs of the Messum, Brandberg and Erongo mountains. Thus dates greater than 2000, but usually not more than 5000, came from Fackeltrager, ${ }^{65}$ Striped Giraffe Shelter ${ }^{66}$ Big Elephant Shelter, ${ }^{67}$ Messum, ${ }^{68}$ Lower Numas Cave ${ }^{69}$ and the Tsisab Shelters. ${ }^{70}$

This seems to reflect different settlement trajectories in different parts of the landscape, possibly in part the result of resource fluctuations. Referring again to van Zinderen Bakker's ${ }^{71}$ model for rainfall patterns in the climatic optimum, we note that he suggests a penetration of 'monsoonal' rains to the escarpment north of the Orange river. Although the Atlantic coast north of the Orange may have been hyper-arid because of the influence of a strong upwelling cell, ${ }^{72}$ the escarpment may have been more attractive then than

${ }_{63}$ PTA-I 1 85, KN-2 I 42: ibid., 51 ; Freundlich, Schwabedissen and Wendt, 'Köln radiocarbon measurements', 76 .

${ }^{64}$ Vogel and Visser, 'Pretoria radiocarbon dates'; Freundlich, Schwabedissen and Wendt, 'Köln radiocarbon measurements'.

${ }_{65} \mathrm{KN}-1.460, \mathrm{KN}-\mathrm{I} .46 \mathrm{I}, \mathrm{KN}-\mathrm{I}$.729, KN-1 .730, KN-I .731, KN-I . 732 : Freundlich, Schwabedissen and Wendt, 'Köln radiocarbon measurements', 78 .

66 Vogel and Visser, 'Pretoria radiocarbon dates', 59.

${ }^{67}$ Ibid., 58-9. Earlier work at Big Elephant Shelter has been reported in J. D. Clark and J. Walton, 'A Late Stone Age site on the Erongo Mountains, South West Africa', S. Afr. Archaeol. Bull., xxxi (1976), I46, and by L. Wadley, 'Big Elephant Shelter and its role in the Holocene prehistory of central South West Africa', Cimbebasia B, III, i (I979), $2-75$.

${ }_{68} \mathrm{KN}-1.636, \mathrm{KN}-1.637, \mathrm{KN}-1.638, \mathrm{KN}-1.639$, PTA-268ı : Vogel and Visser, 'Pretoria radiocarbon dates', 59; Freundlich, Schwabedissen and Wendt, 'Köln radiocarbon measurements', 79-80.

69 PTA-I 295: Vogel and Visser, 'Pretoria radiocarbon dates', 6 I .

i0 PTA-1 546, I 547, I 550, I 773, I 776, I 777 : ibid., 6 I-2.

i1 E. M. van Zinderen Bakker, 'Comparison', 390.

72 Ibid. 
after 6,000 years ago when neither winter nor summer rainfall systems may have penetrated the region. The occupation gap, if such it is, may be analogous to that noted by Janette Deacon ${ }^{73}$ further south and east for a different period. The absence of such a gap further north may reflect the increased opportunities offered by the altitudinal variability of mountainous blocks such as the Brandberg. Clearly, good regional studies will show whether these environmental reconstructions are bedevilled by sampling problems, or whether they are real patterns of settlement shifts.

It does seem likely that the appearance of pastoralists as far south as the Orange river encouraged the reoccupation of the sites which had seen little activity for 4,000 years or so. Such a picture seems increasingly to emerge in many parts of southern Africa as radiocarbon dates accumulate. It is probably reasonable to relate this to the opportunities and problems encountered by dispersed and small populations of hunting and gathering communities when pastoral economies impinged. Competition for wild plant foods and water resources, competition between wild and domestic herbivores, exchange potentials between different technological traditions, mobility between different economic modes of subsistence and partitioning of the landscape are responses that need detecting in the archaeological record.

\section{THE WESTERN AND SOUTHERN CAPE}

Along the southern parts of the Atlantic coastline and in the adjacent coastal plains and mountain folds we now have a substantial sample of radiocarbon dates suggestive of an early Holocene gap in occupation along the coast. In contrast, it seems possible to see, even in this small set of dates, a more continuous occupation through the Holocene in mountain sites.

Specifically, there are no radiocarbon dates from the west coast between about 4,300 and 7,800 years ago, whereas dates from those millennia have been obtained in the adjacent mountain folds from Aspoort, ${ }^{74}$ Klipfonteinrand ${ }^{75}$ and Renbaan. ${ }^{76}$ The dates for this gap are particularly interesting in that they overlap, but are not coterminous with, similar patterns to the north and east. ${ }^{77}$ Aridity along the Atlantic coast is accentuated by the cold upwelled waters of the Benguela current, ${ }^{78}$ which is in turn related to the incidence of southerly winds and their effect in driving surface waters offshore. It is tempting to argue that in the early Holocene millennia upwelling in the southern Benguela cell was more persistent and led to

73 J. Deacon, 'Patterning in the radiocarbon dates'.

i4 PTA-2250, 2422: A. B. Smith and M. R. Rip, 'An archaeological reconnaissance of the Doorn/Tanqua Karoo', S. Afr. Archaeol. Bull., xxxili (i978), i I8-33, and pers. comm.

75 J. C. Vogel, pers. comm.

${ }_{76}$ PTA-3766, 3768, 3783: J. Kaplan, 'Renbaan Cave: stone tools, settlement and subsistence' (Honours dissertation, University of Cape Town, r984).

77 J. Parkington, 'Time and place: some observations on spatial and temporal patterning in the Later Stone Age sequence in southern Africa', S. Afr. Archaeol. Bull., xxxv ( 1980 ), 73-83.

${ }_{78}$ W. R. H. Andrews and L. Hutchings, 'Upwelling in the southern Benguela current', Prog. Oceanogr., Ix ( I 980), I-8 I. 
extremely arid, inhospitable coastal conditions with fewer reliable fresh-water seeps. ${ }^{79}$

There is no doubt that the terminal Pleistocene drowning of river mouths, such as the Olifants and Verloren Vlei, would have created large saline, probably tidal, embayments in what are presently estuaries or 'coastal lakes'. ${ }^{80}$ This same rise in sea level would have drowned the coastal plains, altered the palaeogeography of the coastline, modified resource distributions and destroyed much archaeological evidence for Late Pleistocene settlement. The combination of changing climatic and geographic circumstances seems to have resulted in extremely low mid-Holocene populations along the coast, where no trace is currently recognized. This is all the more striking when the pattern along the southern Cape coast, where the upwelling and aridity are not featured, is compared. Thus sites such as Nelson Bay Cave, ${ }^{81}$ Byneskranskop ${ }^{82}$ and Matjes River Rock Shelter ${ }^{83}$ have long sequences that show no evidence of the hiatus now clearly established for Atlantic coastal settlement. Cape St Francis ${ }^{84}$ and Klasies River Mouth ${ }^{85}$ have also produced mid-Holocene dates.

This lack of any exact fit between the patterns noted for parts of the Holocene in different regions is no doubt the result of complex patterns of synoptic climate. Although an underlying cause in each case may be the climatic adjustments experienced since the last glacial maximum, the lags and interrelations between climate, biota and soils help to generate different settlement trajectories in different regions. ${ }^{86}$

It is worth noting here that the quoted error margin on most radiocarbon determinations from the Western Cape region is less than 80 years. This means that, in theory, patterns on smaller scales than those just described should be meaningfully reflected. An example of such patterning is the series of dates obtained from sites in the western Cape Fold Belt in the past decade. Dates from fairly substantial cave excavations and those from very large, but only minimally excavated, open shell-middens reflect mirror-image patterns. The caves were occupied regularly before about 3,000 years ago and after about I, 800 years ago, but during the intervening thousand years or so the open locations were preferred. Although these sites are within a few kilometres of one another, they have quite different catchment areas. In

${ }^{79}$ Fluctuation in near coastal seeps is one explanation of the sedimentological sequence recently exposed at Spring Cave near the mouth of the Verloren Vlei. These sediments have been examined by $\mathrm{N}$. Lancaster (pers. comm.).

${ }_{80} \mathrm{~J}$. Parkington, 'Landscape and subsistence changes since the last glacial maximum along the western Cape coast', in Olga Soffer (ed.), Regional Perspectives on the Pleistocene Prehistory of the Old World (1986, in press).

${ }^{81} \mathrm{~J}$. Deacon, The Late Stone Age of southernmost Africa (British Archaeological Reports International Series, 213) (Oxford, I 984), I-44I.

${ }^{82}$ F. R. Scheitzer and M. L. Wilson, 'Byneskranskop I. A late Quaternary living site in the southern Cape Province, South Africa', Ann. S. Afr. Mus. Lxxxvili, i, (1982), I-203.

${ }^{83}$ J. T. Louw, 'Prehistory of the Matjes River rock shelter', Memoirs of the National Museum (Bloemfontein) I (1960), I-I 43 .

${ }_{84}$ J. F. Thackeray and F. C. Feast, 'A midden burial from Cape St Francis, eastern Cape Province', S. Afr. Archaeol. Bull., xxix (1 974), 92.

${ }^{85}$ R. Singer and J. Wymer, The Middle Stone Age of Klasies River Mouth in South Africa (Chicago, 1982).

${ }^{86}$ Parkington, 'Landscape and subsistence changes'. 
interpretation, it is suggested that the flat rock platforms in the intertidal zone next to the large open middens were not exposed at low tides by the 'higher' sea level of the fourth millennium B.P., whereas there were moderately productive rocky shores near the caves. ${ }^{87}$ As the sea level fell, or perhaps as coastal warping raised the land, very productive flat platforms were revealed daily by the tides and settlement shifted into the open near these preferred collecting spots. In contrast, the shift of settlement back into caves at about $\mathrm{I}, 800$ years ago is probably more social in origin than it is environmental. It corresponds neatly with the local appearance of ceramics and domestic stock and is therefore probably a response to the appearance of pastoralists. ${ }^{88}$

Andy Smith's ${ }^{89}$ recent research in the granite areas south of the Berg river mouth illustrates patterning at a different scale. Previous work ${ }^{90}$ had tended to regard the pastoralists of the western Cape as 'invisible', arguing that rapid movements in search of pasture and the transport of re-usable equipment resulted in pastoralist debris being thinly scattered over the landscape and archaeologically difficult to recover. But excavations at the granite outcrop of Kasteelberg have shown that this invisibility may be only partial. There are several sites on the Kasteelberg hill, at least two of which are enormous concentrations of shell-midden with abundant ceramics, very large numbers of sheep and cattle bones and dates of I 90 to I, 800 years ago. ${ }^{91}$ Whilst it cannot simply be assumed from the bones and the ceramics that the sites were pastoralist camps, there are certainly marked contrasts with areas to the north, where post-pastoralist accumulations tend to be very small and widespread. There are other indications too, in the relative frequencies of different kinds of fauna, including domestic animals, that persuade Smith and Klein that Kasteelberg was used by the pastoralists themselves. ${ }^{92}$

These contrasts may reflect geographical patterning in the impact of pastoralists in the varied landscape of the western Cape and add further to the complexity of population distribution and interaction in the last two millennia. It is abundantly clear from the geological map of the south-western and western Cape that there are major soil differences from place to place and thus variable pasture quality. The Nama shales north of the lower Olifants river and the Malmesbury shales south of the Berg river generate nutrient-rich soils and thus attractive pasturage for stock. But between these

${ }^{87}$ There is considerable discussion in the literature as to whether Holocene features around the shores of southern Africa lying 2-3 metres above present sea-level result from a higher stand of the sea or an emergence of the land. The most general model is given by J. A. Clark, W. E. Farrell and W. R. Peltier, 'Global changes in post-glacial sea level: a numerical calculation', Quaternary Research, Ix (1978), 265-87; and by J. A. Clark and C. S. Lingle, 'Predicted relative sea-level changes ( 18000 years BP to Present) caused by late-glacial retreat of the Antarctic ice sheet', Quaternary Research, xI (I 979), 279-98.

${ }^{88}$ A. H. Manhire, J. E. Parkington and T. S. Robey, 'Stone tools and sandveld settlement', in Hall et al. (eds.), Frontiers, I I I-I 20.

${ }^{89}$ A. B. Smith, 'Prehistoric pastoralism in the Southwestern Cape, South Africa', World Archaeology, xv, i ( 1983 ), 79-89; A. B. Smith, 'Adaptive strategies of prehistoric pastoralism in the south-western Cape', in Hall et al. (eds.), Frontiers, I3 I-42.

${ }_{90} \mathrm{P}$. T. Robertshaw, 'Coastal settlement, freshwater fishing and pastoralism in the later prehistory of the western Cape, South Africa' (Ph.D. thesis, University of Cambridge, 1979).

${ }^{91}$ PTA-364 I, 37 I I, 3737, 3742, 3747, 3785, 3787, 3788: A. B. Smith, pers. comm.

92 A. B. Smith and R. Klein, pers. comms. 
two zones are the sandstone-derived soils that support various kinds of fynbos heathland vegetation and the deeper sands of the sandveld with strandveld shrubland vegetation. ${ }^{93}$ Although the relatively unleached calcareous sands near the coast may be less depleted of nutrients than the thin sandstone soils to the east, both of these are relatively unattractive to stock-keepers, especially those with large herds of cattle. ${ }^{94} \mathrm{We}$ may have to envisage the coastal plain between the lower Berg and Olifants rivers as a kind of pastoralist expansion zone, used when conditions were good, or pasture in particular demand, but not as unambiguously controlled by pastoralist groups as the areas further north and south. ${ }^{95}$

Some more viable hunter-gatherer strategies may have been possible here, whereas elsewhere clientship or complete integration may have be:n unavoidable. If some kind of residual, albeit stressed, hunter-gatherer settlement in the last two millennia was possible in some areas but less so in others, there should be some reflexion of this in the distribution of recent stone-tool scatters and rock paintings. Indeed, it has long been known that there are few rock paintings within roo kilometres of the Cape, although this may have much to do with greater rainfall and unsuitable rock surfaces. ${ }^{96}$ It is already quite clear that we need good regional sequences extending back 3,000 years or so in all the areas close to those known historically to have been used for pasture by Khoi. Experience in the western Cape leads us to expect different settlement histories, at least in part resulting from the patterning of soil nutrients and surface water and the implications of these for pastoralisthunter interactions. It can no longer be assumed that the eastern, southern and western Cape displayed a uniform response to the appearance of pastoralism or that the period between I,700 and 300 years ago saw a stable or static social scenario.

\section{EASTERN PLATEAU SLOPES}

New dates reported here and in previous reviews are particularly fascinating in the region of the Eastern Plateau slopes because it is here that farming communities are traditionally supposed to have penetrated the southern parts of Africa ${ }^{97}$ If, as seems likely, farmers were drawn to the easily worked fertile soils of the alluvial valleys of south-east Africa, then some interesting interactions with indigenous hunter-gatherers may be expected. It is disappointing, then, to find in the literature almost no mention of these issues and, until recently, little ecologically orientated attention to the processes of the supposed expansion. ${ }^{98}$ Ideas about the spread of farming, usually

${ }^{93}$ E. J. Moll and M. L. Jarman, 'Is fynbos a heathland?', S. Afr. F. Sci., Lxxx, viii (1 984), 352-4.

${ }_{94}$ E. Moll, pers. comm.

${ }_{95}$ N. Penn, pers. comm.

${ }_{96} \mathrm{~T}$. Maggs, pers. comm.

${ }_{97}$ T. Maggs, 'The Iron Age south of the Zambezi', in R. G. Klein (ed.), Southern African Prehistory and Palaeoenvironments (Rotterdam, 1984).

${ }_{98}$ Exceptions are T. Maggs, 'The Iron Age sequence south of the Vaal and Pongola Rivers: some historical implications', F. Afr. Hist., xxI, i (1980), I-1 5 ; M. Hall, Settlement Patterns in the Iron Age of Zululand (British Archaeological Reports International Series, I I9) (Oxford, I98I), I-I9I; and Peta Jones, 'Mobility and migration in traditional African farming and Iron Age models', in Hall et al. (eds.), Frontiers, 289-96. 
considered synonymous with that of Bantu languages and iron-working, are almost all based on ceramic patterns and linguistic histories. Arrows have been drawn across the map connecting similar ceramic assemblages, often with minimal attention to the mechanisms of movement or the social and environmental contexts of expansion. ${ }^{99}$ The presence of a particular kind of potsherd decoration on a site is usually thought enough to proclaim the site 'Iron Age' and thus, by implication, occupied by Bantu-speaking, negroid farmers. ${ }^{100}$ We suggest that, in some of the dates listed in the Appendix, we have evidence that things were far more complex than this.

The sites of Umbeli Belli and Mpambanyoni, for example, are only a few kilometres apart in the lower reaches of the Mpambanyoni river, and were occupied more or less contemporaneously by people considered 'Stone Age' and 'Iron Age' respectively. The shelter of Umbeli Belli has fairly shallow deposits, the upper levels of which contain a few potsherds in association with faunal remains that reflect a largely hunting and gathering way of life. ${ }^{101}$ Mpambanyoni was, by contrast, one of several very large open shell-middens on a low hill and produced a very substantial sample of potsherds considered 'Iron Age' and a hint - no more - of domestic animals. ${ }^{102}$ Otherwise the shell-midden was dominated by marine foods and wild game.

Ethnographic and historic accounts of hunter-gatherer/farmer interactions suggest that technological items such as ceramics and metal are widely exchanged and thus rapidly cease to function as markers of different segments of regional populations. ${ }^{103}$ It is obvious that the 'role' of each site has to be established with reference to others in the contemporary landscape before some reconstruction of regional economics can begin. In this sense sites have no autonomy, and must rather be seen as forming pieces of a jigsaw puzzle. Is it not likely that hunter-gatherers survived in the densely bushed coastal forest of south-east Africa, specializing in forest products and operating on the fringes of farming communities, and that Mpambanyoni and Umbeli Belli were part of the same system of settlements, rather than representatives of discrete 'ages'?

Perhaps the less substantial shell middens further north and south of Mpambanyoni make this point even more effectively. Mpame, ${ }^{104}$ for example, is one of several dozen sites located by Mike Cronin as part of a survey of the coast of Transkei. These are all coastal shell-middens, some of them very small, in which the faunal remains clearly document a largely hunting and gathering economy, though in a few there are very fragmentary pieces of

99 For examples of this approach see D. W. Phillipson, The Iater Prehistory of Eastern and Southern Africa (London, I 977); T. N. Huffman, 'African origins', S. Afr. F. Sci., LXXV (I 979), 233-7.

100 For a critique of this assumption see M. Hall and A. Morris, 'Race and Iron Age human skeletal remains from southern Africa: an assessment', Social Dynamics Ix, ii ( с 983 ), 29-36.

${ }_{101}$ PTA-2824, 2825. J. H. C. Cable, Economy and Technology in the Late Stone Age of Southern Natal (British Archaeological Reports International Series, 20 I) (Oxford, I 984 ), I-267.

${ }^{102}$ PTA-2527, 2528: T. Robey, 'Mpambanyoni: a Late Iron Age site on the Natal south coast', Ann. Natal Mus., Xxiv, i ( I 980), i63.

103 Denbow and Wilmsen, 'Iron Age pastoralist settlements'.

104 PTA-20I7: M. Cronin, 'Radiocarbon dates for the Early Iron Age in Transkei', S. Afr. F. Sci., lxxvir, i (1982), 38 . 
domestic animal bone. Ceramics of a kind generally referred to as 'Iron Age' are found on some of the sites and are common on a few, Mpame being one of these.

One of the things that makes this site-distribution pattern interesting is the contrast it forms with the modern pattern of shell-midden accumulation. As reported by Voigt and Bigalke, ${ }^{105}$ women collectors along this coast come to the shore at low spring tides, collect shellfish and take them back to agricultural villages located some kilometres inland, usually on the interior margin of the thick coastal forests. Although the women 'snack' whilst they work, no midden accumulates at the collecting location. The dates from Mpame show that for a half-millennium or more, albeit sporadically, a quite different system operated.

Several conventional explanations for the earlier pattern are possible. It could be that the shell-middens represent the debris of specialized workparties visiting the coast to collect shellfish and returning to villages in the interior. Perhaps some shellfish was consumed during overnight stops at the coast, in contrast to the current situation. Alternatively, the middens could reflect a less regular strategy, perhaps one resorted to only in periods of short-term crises in subsistence efficiency. ${ }^{106} \mathrm{It}$ is possible, though perhaps very unlikely, that Mpame and other sites reflect agricultural villages where shellfish were gathered. But, despite their differences, the above propositions all assume that agriculturalists left the shell debris themselves. This, however, may not have been the case. The middens could be the occupation sites of client or even relatively independent groups of hunter-gatherers who survived by exploiting resources ranked low by neighbouring agriculturalists in areas too densely bushed to be attractive to cattle keepers. Clearly the domestic stock and ceramics imply some form of interaction, but they do not reveal its nature unless placed in a wider perspective.

Enkwazini near Lake St Lucia, ${ }^{107}$ and Matola in southern Mozambique, ${ }^{108}$ are likewise shell-middens with only minimal evidence for the status 'Iron Age'. The late date for cave-dwelling, stone tool-using people at Umbeli Belli ${ }^{109}$ and Mhlanga ${ }^{110}$ remind us that hunter-gatherers may have survived I, 500 years of agricultural occupation. The swathe of shell-middens along the south-east African coast from the mouth of the Zambezi to the mouth of the Kei may reflect the existence of a viable refuge area for huntergatherers. In fact, Acocks ${ }^{111}$ suggested that the coastal subtropical forests were much more substantial prior to the penetration of farmers with domestic plants and stock. The combination of dense forest and productive intertidal zone may have afforded residual hunter-gatherers the resource base from which to maintain symbiotic relations with increasing numbers of farmers.

105 E. Voigt and E. H. Bigalke, 'The interdisciplinary aspect of a study of shellfish exploitation by indigenous coastal communities', S. Afr. Mus. Bull., x, vii ( I973), I-I6.

106 E. Colson, 'In good years and in bad: food strategies of self-reliant societies',

F. Anthrop. Res., xxxv, i (1979), I 8-29.

107 PTA-I 848, 2485, 2537: Hall, Settlement patterns, I-I 9 I.

108 ST-8546, 8547, 8548: J. Morais, 'Mozambican archaeology: past and present', Afr. Archaeol. Rev., II ( 1 984), i I 3-28.

109 Cable, 'Economy and technology'.

110 PTA-3268: T. Maggs, pers. comm.

111 J. P. H. Acocks, 'Veld types of South Africa', Memoirs of the Botanical Survey of South Africa, XL ( 1975 ), map I. 
As the scale of farming increased, forests would have been reduced and the viability of such an option may have decreased. ${ }^{112}$

It is probable that similarly complex interactions took place across inland 'frontiers' as well. Both Tim Maggs ${ }^{113}$ and Aron Mazel ${ }^{114}$ have suggested that 'Iron Age' and 'Stone Age' communities in the Thukela River basin may have been exchanging commodities from the earliest years of farming, and recently obtained radiocarbon dates from rockshelters in the upper catchment areas of the river certainly indicate a sustained period of overlap. Thus Clarke's Shelter, ${ }^{115}$ Gehle Shelter ${ }^{116}$ and Nkupe Shelter, ${ }^{117}$ while occupied initially from as early as the seventh millennium B.C., continued to be used after the farming way of life had been established in the lower-lying river valley.

\section{IS CUSSION}

A comparison of the radiocarbon dates presented in this review with those available in 1980 and $1977^{118}$ will show that, with some exceptions, the chronological framework for the later prehistory of southern Africa has now been established for some time. In this circumstance, new dates have begun to take on a different role, elucidating the subtleties of human behaviour. This in turn demands a careful consideration of the sort of information that a new radiocarbon date can carry.

A basic point is that dates may be associated quite unambiguously with materials such as ceramics, bones, stone tools or structures, but do not reflect in any direct sense underlying behaviours such as manufacture, mode of acquisition or context of use. Thus, even if good stratigraphic relationships between charcoal samples and, say, certain types of ceramics or domestic animal bones can be demonstrated, this association does not reflect whether the pots were made, traded or stolen by the site occupants or whether the animals were hunted or herded. Such questions must be tackled through the formal and spatial properties of the archaeological record (site locations, animal age profiles, sources of clays, evidence of enclosures), and with hypotheses generated from elsewhere. There is a difference between confirming the existence of domestic animals or ceramics in an area and hypothesizing that such artefacts or bones were made or left at specific sites by people with particular subsistence economies.

In turn, this leads us to question the continued relevance of the concept of 'ages' which, with its roots in the classic, early nineteenth century three-system of Europe, ${ }^{119}$ seems particularly inadequate when applied to

112 Aron Mazel is currently exploring the interaction between hunters and farmers in his Natal research.

${ }^{113}$ T. Maggs, 'Msuluzi Confluence: a seventh century Early Iron Age site on the Tugela River', Ann. Natal. Mus., Xxiv, i (1980), I I I-45.

${ }_{114}$ A. Mazel, 'Through the keyhole: a preliminary peep at the lithic composition of Later Stone Age sites in the central and upper Tugela River basin, Natal', in Hall et al. (eds.), Frontiers, $182-93$.

115 PTA-2971, 2973, 3247: ibid., 185.

116 PTA-3242, 3243, 3245: ibid., 186.

117 PTA-3269, 3275, 3276, 3443, 3455, 3460: ibid., 187.

118 Maggs, 'Dates'; Hall and Vogel, 'Recent radiocarbon dates'.

119 G. Daniel, A Hundred and Fifty Years of Archaeology (London, 1975). 
prehistoric times of great technological and demographic dynamism such as the last two millennia in southern Africa. Sequential temporal blocks or, less appropriately, contemporary but separate streams, may merit the term 'ages', but the blended traditions and interactive complexity which emerge seem particularly unsuited to this form of terminology. A more subtle approach may well tease out complex intergroup relationships where boundaries of various kinds (linguistic, economic, technological) do not necessarily coincide and where typological classification is inappropriate. In fact, radiocarbon dates, by virtue of the impact they have had in illustrating the antiquity of pastoralism, agriculture, ceramics and iron technology, have innocently been used to mask what must have been very complex intergroup relations over long periods. The search for the 'earliest sheep' or the 'first evidence of pastoralism' has often diverted attention away from the social interactions which followed episodes of introduction or immigration.

When the 'age system' is set to one side, two dominant themes emerge from the regional synthesis of recent radiocarbon dates. The first is the suggestion that time-space patterns in dates may, albeit fuzzily, reflect real shifts in prehistoric settlement through the Holocene. We will not be sure that this is the case until researchers specifically note gaps in the record and reorganize their fieldwork and submission of dates around testing observed patterns. This will certainly mean obtaining many more dates, and sampling in such a way as to distinguish between periods of regular deposition and periods of relative avoidance. Research design will then have to distinguish regional from local patterns and to detect shifts in the choices of sites, as from open to cave situations, for example.

The second theme is the recognition that intergroup relations during the past two millennia have been variable and complex. It is clear that no hunter-gatherer communites have been described ethnographically in isolation from other economic systems and that interaction, whether co-operative or conflictive, is the rule rather than the exception. ${ }^{120}$ As noted by Alexander ${ }^{121}$ and Giliomee, ${ }^{122}$ there have been at least three movements of frontier through southern Africa in the last two thousand years. The most recent, the spread of colonial farming, was partly documented historically by one party to the interaction, but the other two, the spread of pastoralism in the west and agriculture in the east, were not, and have to be documented by archaeological research. What we need are, on the one hand, a set of expectations as to what kinds of interaction may characterize each particular context and, on the other, archaeological methods to apply in, and on, the ground.

The expectations must surely come from a thorough grounding in the ethnography of southern Africa and in the ecological circumstances in which the interaction evolved or occurred. It seems clear, for example, that for long-term symbiotic relations to evolve between incoming agriculturalists and indigenous hunter-gatherers there has to be some kind of refuge area where, at least temporarily, hunting and gathering is deemed more viable

120 E. Leacock and R. Lee, Politics and History in Band Societies (Cambridge, 1982).

121 Alexander, 'Early frontiers'.

${ }^{122} \mathrm{H}$. Giliomee, 'Processes in development of the southern African frontier', in H. Lamar and L. Thompson (eds.), The Frontier in History (New Haven, 1981). 
than farming. Rugged mountains, forests, swamps or tsetse-infested areas may provide the kinds of ecological circumstances where mutually interdependent economies can be juxtaposed. We suggested earlier that the extensively forested eastern seaboard of south-east Africa, along with the coastal fringe, may have contrasted with the middle reaches of the local rivers and allowed hunters and farmers to have co-existed for more than a millennium. The forests are today fragmented and reduced, probably the result of encroachment, leading to an increasingly marginal trajectory for the hunters.

Ethnographic and historic records also help to predict what kinds of interaction may be expected. Honey, for example, is almost synonymous with the interests of African hunter-gatherers. ${ }^{123}$ Along with skins, ivory and other 'bush' products, honey is often the hunter-gatherer's produce available for exchange. But it is also possible that hunters choose to intensify their protein gathering and exchange meat for carbohydrates. Relations between hunters and pastoralists without grains, such as the Khoi, may have been quite different and, perhaps, less symbiotic. Without the complementary potential of carbohydrate and protein to exchange, hunters and herders may have competed more directly for pasture, water, game and wild plant foods. Absorption, or retirement into isolation, may have been the alternatives for such hunter-gatherer groups.

Another expectation relates to the nature of frontiers. Alexander ${ }^{124}$ notes that, particularly in the early phase of the moving frontier, pioneering communities influence indigenous groups many kilometres ahead of their actual presence. What all this seems to mean is that in order to formulate expectations about the nature of interaction between hunter-gatherers and people with domestic plants and/or animals we would need an understanding of the pre-contact settlement system, including the relative use of different landscape segments, the choice of camp locations and the range of dietary items regularly used. We could then speculate on the effects of intrusion on population distribution, mobility and dietary breadth after contact, bearing in mind the range of technological items brought in by the newcomers. In this review we have been at pains to describe patterning that is emerging in radiocarbon dates that long precede the conventional time-horizon for the introduction of food production in southern Africa, precisely because we believe that a thorough understanding of this earlier context is essential if the full depth of the pastoralist and agricultural frontiers is to be appreciated.

In understanding interactions at such frontiers, optimal foraging modelling may well prove appropriate. ${ }^{125} \mathrm{~A}$ factor of considerable importance here is the scheduling of time. Hunter-gatherer groups exposed to the options of crop planting and animal husbandry would obviously have to consider the competing requirements of alternative food-gathering or production strategies in terms of time. Daily, seasonal and perhaps other patterns of

123 For example, the Okiek: R. H. Blackburn, 'In the land of milk and honey; Okiek adaptations to their forests and neighbours', in Leacock and Lee, Politics and History, $283-305$.

124 Alexander, 'Early frontiers'.

125 R. L. Bettinger and M. A. Baumhoff, 'The numic spread: Great Basin cultures in competition', American Anthropology, xiviI, iii ( 1982), 485-503. 
time-allocation may force people to choose between the advantages of a compromise solution and those of a specialized system with the option of exchange with nearby similarly specialized groups. Such analyses would also have to accommodate patterns of differential activities and time budgets between men and women.

Although a precise chronology would certainly be needed, the archaeological methods for detecting and specifying such interaction would need to seek composite patterns involving space, time and form. Site distributions, for example, would help distinguish between retreat into relative isolation and movement into areas strategically located for exchange, perhaps seasonally. Examples of these latter are well developed in the literature on Ndorobo, Pygmy and Punan groups. ${ }^{126}$ Many of the patterns in radiocarbon dates listed here may well illustrate coherent shifts in population distribution as a direct response to the incursion of pastoralists or agriculturalists. It would also be important to note on what kinds of sites the first signs of contact appear, and to distinguish between first contact, regular contact and mature contact.

In conclusion, it is clear from this review that the role of radiocarbon dating in southern African archaeological research is at a threshold. The outline of chronology is now well established and has not been subsequently altered by dates reported in this article, or indeed in other recent reviews. But on the other hand, the intensity of radiocarbon dates from specific regions, that have been linked to specifically designed research problems, is still too low to allow firm conclusions about the more subtle patterns in prehistoric behaviour that have been tentatively suggested on preceding pages. ${ }^{127}$

\section{SUMMARY}

Radiocarbon dates published by southern African archaeologists since the last review in this journal (in I980) illustrate an increasingly complex record of population movement and interaction. Substantial gaps in the distributions of dates reflect the ebb and flow of people in response to changing environmental and social circumstances. More interesting perhaps is the range of intergroup relations now emerging from the last two millennia with the appearance of pastoralists and agriculturalists. Radiocarbon dates, taken along with spatial and formal patterns in the archaeological record, show clearly that the distributions between hunters, herders and farmers and between Stone Age and Iron Age communities were blurred and flexible.

${ }^{126}$ See Blackburn, 'In the land of milk and honey'; C. L. Hoffman, 'Punan foragers in the trading networks of south-east Asia', in C. Schrire (ed.), Past and Present in Hunter-gatherer Societies (New York, 1984).

${ }^{127}$ We would like to thank Curtis Marean, ' $T$ ' Farrar, Rob Blumenshine, Preston Miracle and Charles McNutt, all of Berkeley, and Royden Yates, Tony Manhire and Alyson Herlihy in Cape Town. 


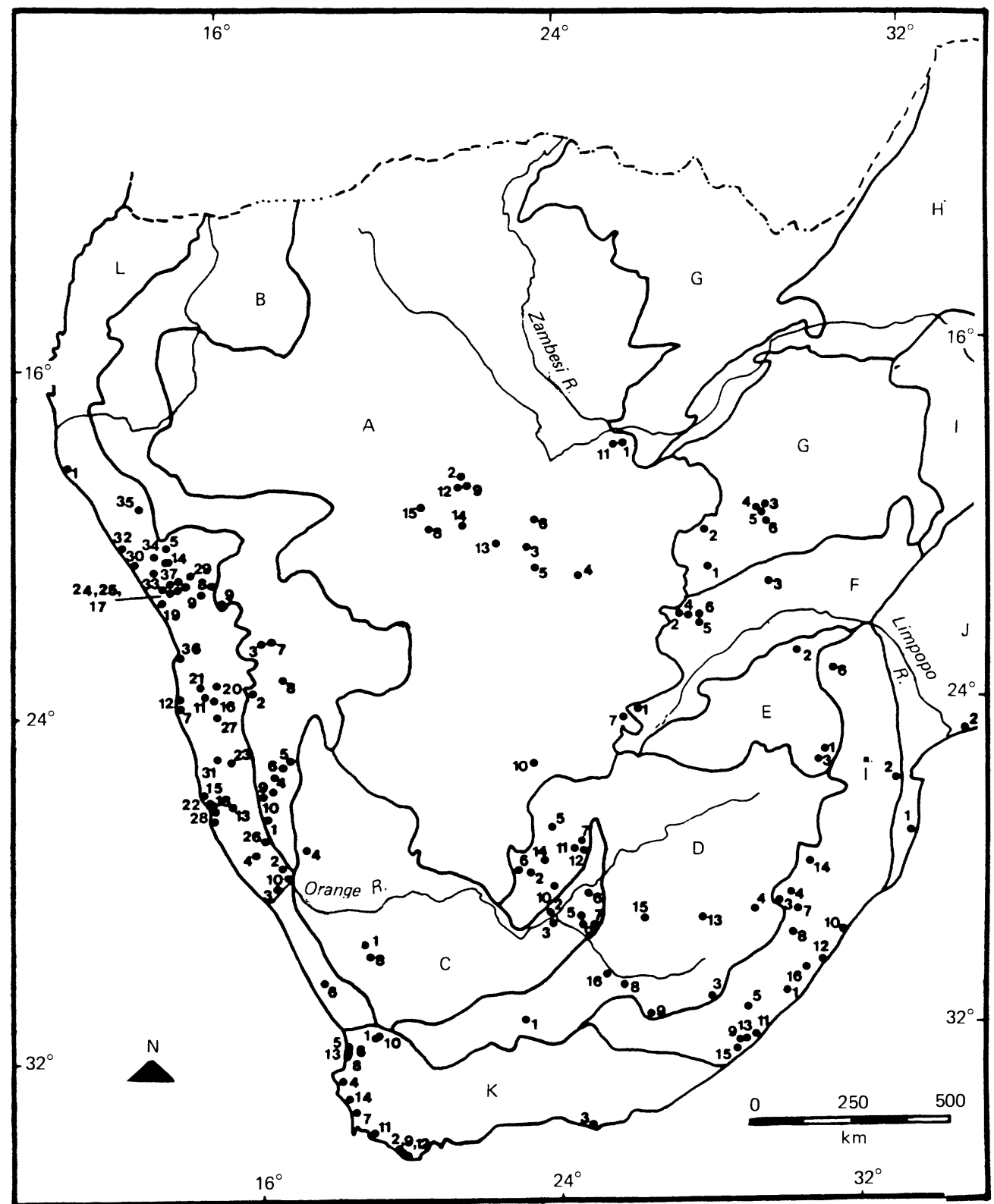

Fig. I. Geographical zones with site-locations

A Kalahari Basin

B Western Peripheral Highlands

C Cape Middleveld

D South African Highveld

E Transvaal Plateau Basin

F Limpopo-Sabi Depression
G Zimbabwe Uplands

H Zambezi-Nyasa Trough

I Eastern Plateau Slopes

J Mozambique Plain

K Southern Cape

L Atlantic Coast Region 


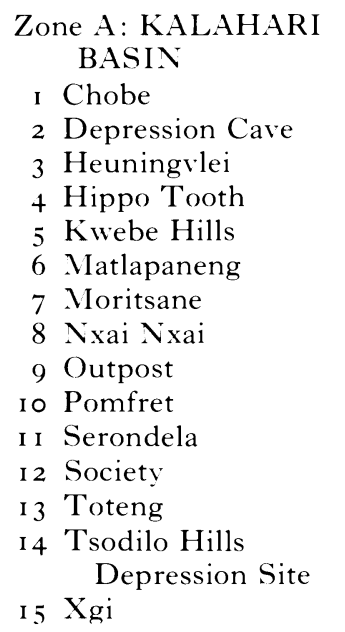

Zone B: W. PERIPHERAL HIGHLANDS

I Aar

2 Cha-re Shelter

3 Friedenau Shelter

4 Kumakams

5 Maguams

6 Namtib

7 Otjampaue

8 Rehoboth

9 Striped Giraffe Shelter

Io Tiras 5

Zone C: CAPE MIDDLE-
VELD
I Bitterputs I
2 Dikbosch
3 Douglas
4 Huns
5 Khartoum
6 Kimberley
7 OFD I
8 Suurwater
9 Waterval West

Zone D: SOUTH AFRICAN HIGHVELD

I Biessiesfontein

2 Blinkklipkop

3 Colwinton Rock Shelter

4 Diamond I

5 Dithakong I

6 Doornfontein

7 Equus Cave

8 Glen Elliot Shelter

9 Grassridge Rock Shelter

Io Limerock I Shelter

\section{KEY TO MAP}

I I Little Witkrans Shelter

12 Norlim 5

13 Rose Cottage Cave

I4 Wonderwerk Cave

I 5 Voigtspost $\mathrm{O}$

I6 Zaayfontein Shelter

\section{Zone E: TRANSVAAL PLATEAU BASIN \\ I Bamboo \\ 2 Doornkop \\ 3 Klein Africa}

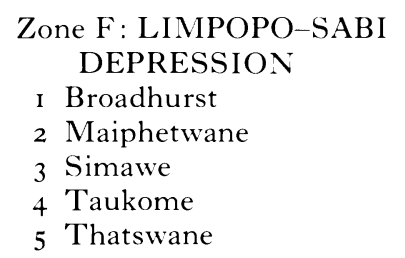

\section{Zone G: ZIMBABWE} UPLANDS

I Bisoli

2 Dombashaba

3 Mwala Hill

4 Nali Hill

5 Norfolk Road

6 Rennydene

\section{Zone $\mathrm{H}$ : ZAMBEZI- NYASA TROUGH \\ No dates}

\section{Zone I : EASTERN PLATEAU SLOPES}

I Borcher's Shelter

2 Caimane

3 Clarke's Shelter

4 Driel Shelter

5 Dwesa 3002

6 Eiland Saltworks

7 Gehle Shelter

8 Good Hope Shelter

9 Lujojozi 3027

Io Mhlanga Lagoon

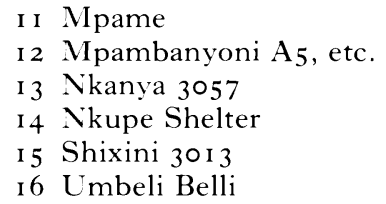

Zone J : MOZAMBIQUE PLAIN

Enkwazini

2 Matola

\author{
Zone K : SOUTHERN \\ CAPE \\ I Andriesgrond \\ 2 Byneskranskop \\ 3 Cape St Francis \\ 4 Kasteelberg A,B,C \\ 5 Kreefbaai \\ 6 Lambert's Bay \\ 7 Melkbostrand \\ 8 Mussel Point \\ 9 Pearly Beach \\ Io Renbaan \\ I I Rooiberg \\ 12 Soetfontein \\ 13 Tortoise Cave \\ I4 Ysterfontein
}

\section{Zone L: ATLANTIC COAST REGION}

I Angra Fria

2 Apollo

3 Arrisdrift

4 Aurus

5 Austerlitz

6 Bethelsklip

7 Conception

8 Etemba

9 Fackeltrager

Io Fish River

I I Gorob Mouth

I 2 Grillenberg

I 3 Haalenberg

I4 Hasenbild

I 5 Hottentot Bay

I6 Hudaob

I7 Hungarob

I 8 Luderitz

I9 Messum

20 Mirabib

2I Narob Grave

22 Nautilus Pot

23 Nos

24 Orabes Schlucht series

25 Numas Schlucht series

26 Pockenbank

27 Sossusvlei

28 Steenbrass Bay

29 Tsisab Schlucht series

30 Twyfelfontein

3 I Uri-Hauchab

32 Unjab Midden

33 Ugab River site

34 Ururu

35 Warmquelle

36 Wortel

37 Zwei Schneider 


\section{A P PENDIX}

RADIOCARBON DETERMINATIONS NOT PREVIOUSLY LISTED IN THIS JOURNAL

\begin{tabular}{|c|c|c|}
\hline Nxai Nxai & Beta 3970 & $720 \pm 50$ a.d. \\
\hline $\begin{array}{l}\text { Shixini } 30 \text { I } 3 \\
\text { (charc.) }\end{array}$ & Beta I I I I I & $1750 \pm 70$ a.d. \\
\hline $\begin{array}{l}\text { Shixini 30I } 3 \\
\text { (shell) }\end{array}$ & Beta I I I I 2 & $70 \pm 60$ b.c. \\
\hline $\begin{array}{l}\text { Lujojozi } 3027 \\
\text { (charc.) }\end{array}$ & Beta I I I 3 & $710 \pm 70$ a.d. \\
\hline $\begin{array}{l}\text { Lujojozi } 3027 \\
\text { (charc.) }\end{array}$ & Beta I I I I 4 & $470 \pm$ 100 a.d. \\
\hline $\begin{array}{l}\text { Dwesa } 3002 \\
\text { (shell) }\end{array}$ & Beta I I552 & $2580 \pm 80$ b.c. \\
\hline $\begin{array}{l}\text { Dwesa } 3002 \\
\text { (charc.) }\end{array}$ & Beta I I 553 & $3460 \pm \mathrm{I} 65$ b.c \\
\hline Thatswane & I- I I.407 & $685 \pm 80$ a.d. \\
\hline Taukome & I - I I.409 & $955 \pm 750$ a.d. \\
\hline Thatswane & $\mathrm{I}-\mathrm{I} 1.4 \mathrm{IO}$ & $710 \pm 80$ a.d. \\
\hline Society & $\mathrm{I}-\mathrm{I} \mathrm{I} .4 \mathrm{I} I$ & I $840 \pm 80$ a.d. \\
\hline Tautswe & I I I $.4: 2$ & I $195 \pm 75$ a.d. \\
\hline Thatswane & I - I I . 4 I 4 & $925 \pm 80$ a.d. \\
\hline Thatswane & I - I I 4 I 5 & II IO \pm 75 a.d. \\
\hline Moritsane & I - I I .823 & $1095 \pm 75$ a.d. \\
\hline Depression Cave & I - I I .824 & $\mathrm{I} 645 \pm 75$ a.d. \\
\hline Kwebe Hills & I - I 2.163 & $1755 \pm 75$ a.d. \\
\hline Hippo Tooth & I - I 2.165 & $830 \pm 190$ a.d. \\
\hline Bisoli & I - I 2.708 & $710 \pm 80$ a.d. \\
\hline Serondella & I - I 2.798 & I I $50 \pm 80$ a.d. \\
\hline Serondella & I - I 2.799 & $730 \pm 80$ a.d. \\
\hline Chobe & I - I 2.800 & $760 \pm 80$ a.d. \\
\hline Matlapaneng & $\mathrm{I}$ - I $2.80 \mathrm{I}$ & $680 \pm 80$ a.d. \\
\hline Toteng & I - I 3.180 & $155^{\circ} \pm \mathrm{r} 00$ a.d. \\
\hline $\begin{array}{l}\text { Tsodilo Hills } \\
\text { Depression site }\end{array}$ & I-I 3.182 & $1580 \pm 75$ a.d. \\
\hline Fackeltrager P. I & $\mathrm{KN}-1.460$ & $990 \pm 45$ b.c. \\
\hline Fackeltrager P.2 & $K N-1.46 I$ & $960 \pm 45$ b.c. \\
\hline Etemba 2 & $\mathrm{KN}-\mathrm{I} .46_{5}$ & $20 \pm 50$ a.d. \\
\hline Etemba I 4 & $\mathrm{KN}-1.467$ & I $530 \pm 60$ a.d. \\
\hline $\begin{array}{l}\text { Twyfelfontein } \\
\text { 'Affenfelsen' }\end{array}$ & $\mathrm{KN}-\mathrm{I} .468$ & $1500 \pm 40$ a.d. \\
\hline $\begin{array}{l}\text { Twyfelfontein } \\
\text { 'Hassenbild' }\end{array}$ & $\mathrm{KN}-\mathrm{I} .469$ & I $580 \pm 50$ a.d. \\
\hline Pockenbank PI.I & $\mathrm{KN}-1.624$ & $4960 \pm 45$ b.c. \\
\hline A Aar I & KN-1.630 & I $890 \pm 50$ a.d. \\
\hline B Aar I & $\mathrm{KN}-\mathrm{I} .630$ & I $840 \pm 60$ a.d. \\
\hline Maguams-Andalusia P.I & KN-I.63I & $1460 \pm 50$ a.d. \\
\hline Maguams-Andalusia P.2 & $\mathrm{KN}-1.632$ & $4010 \pm 60$ b.c. \\
\hline Maguams Terrace & $\mathrm{KN}-1.633$ & I $380 \pm 55$ b.c. \\
\hline Uri-Hauchab 4 & KN-1.634 & $1910 \pm 50$ a.d. \\
\hline Austeralitz & KN-1.635 & $1040 \pm 55$ a.d. \\
\hline Messum PI & KN-1.636 & I090 \pm 55 a.d. \\
\hline Messum $\mathrm{P}_{2}$ & KN-I.637 & I $20 \pm 90$ b.c. \\
\hline Messum $\mathrm{P}_{3}$ & KN-1.638 & $870 \pm 55$ b.c. \\
\hline Messum $\mathrm{P}_{4}$ & KN-1.639 & I $40 \pm 45$ b.c. \\
\hline Tiras 5 & $\mathrm{KN}-\mathrm{I} .728$ & I910 \pm 50 a.d. \\
\hline
\end{tabular}


Fackeltrager B. I

Fackeltrager B.4

Fackeltrager B.3

Fackeltrager B.2

Huns

Namtib P. I

Namtib P.2

Doornfontein

Rose Cottage Cave

Rehoboth I

Rehoboth 2

Rehoboth 3

Angra Fria 3

Angra Fria I

Angra Fria 2

Good Hope Shelter

Ysterfontein

Melkbostrand

Ysterfontein

OFD I

Mirabib

Steenbrass Bay $\mathrm{S}_{\mathbf{I}}$

Steenbrass Bay $\mathrm{S}_{2}$

Aar 2.PI

Steenbrass Bay $\mathrm{S}_{3}$

Aar 2. $\mathrm{P}_{2}$

Nos $\mathrm{P}_{2}$

Nos $P_{1}$

Tiras 5.PI

Tiras $5 \cdot \mathrm{P}_{2}$

Namtib P.I

Namtib P.2

Pockenbank $\mathrm{V}_{5}$

Lower Numas Cave L61

Mirabib 7

Mirabib 6

Grosse dom Schlucht $\mathrm{H}_{4}$

Driel Shelter

Good Hope Shelter

Voigtspost $\circ$

Dikbosch 2

Eiland Saltworks

Eiland Saltworks

Mirabib I 2

Tsisab Shelter $\mathrm{T}_{3 \cdot \mathrm{I}}$

Girls' School Shelter T6.I

Ostrich Shelter $T_{3.2}$

Ostrich Shelter $\mathrm{T}_{3 . \mathrm{I}}$

Eiland Saltworks

Limerock Shelter

Hungarob pot

Eiland Saltworks

Eiland Saltworks

Eiland Saltworks

Aar 2. $\mathrm{P}_{3}$

Limerock 2 Shelter

Girls' School Shelter T6.A2
$\mathrm{KN}-1.72$

KN-1.730

$\mathrm{KN}-1.73 \mathrm{I}$

$\mathrm{KN}-1.732$

$\mathrm{KN}-2$ I 4 I

$\mathrm{KN}-2 \mathrm{I} 42$

$\mathrm{KN}-2 \mathrm{I} 43$

PTA I 86

PTA 350

PTA 432

PTA 433

P'TA 434

PTA 722

PTA 730

PTA 826

PTA 838

PTA 926

PTA 928

PTA 929

PTA 964

PTA IOII

PTA 1042

PTA I045

PTA 1046

PTA 1049

PTA 1050

PTA I I 3 I

PTA I I 32

P'TA II 83

PTA I I 84

P'TA I I 85

PTA I I 86

PTA I 202

P'TA I 295

P'TA I 347

PTA I 348

PTA I 377

P'TA I 38 I

PTA I 480

P'TA 1483

P'TA I 507

PTA I 512

PTA I 522

P'TA I 536

PTA I 546

PTA I 547

P'TA I 550

PTA I $55 \mathrm{I}$

P'TA I 589

PTA 1621

P'TA I 625

P'TA I 668

P'TA I 745

P'TA I 746

P'IA $175 \mathrm{I}$

P'TA 1759

P'TA 1773
I $720 \pm 50$ a.d.

$890 \pm 55$ b.c.

$200 \pm 60$ b.c.

$240 \pm 40$ b.c.

$1700 \pm 70$ a.d.

$5610 \pm 75$ b.c.

$6280 \pm 70$ b.c.

$830 \pm 40$ a.d.

I $340 \pm 50$ a.d.

$1730 \pm 50$ a.d

I $720 \pm 40$ a.d.

$1700 \pm 45$ a.d.

I $870 \pm 50$ a.d.

I $640 \pm 50$ a.d.

I $750 \pm 40$ a.d.

$210 \pm 40$ b.c.

$460 \pm 55$ a.d.

I $270 \pm 55$ b.c.

$930 \pm 50$ b.c.

I $660 \pm 45$ a.d.

$3240 \pm 75$ b.c.

$490 \pm 50$ b.c.

$590 \pm 70$ b.c.

I $850 \pm 45$ a.d.

I $20 \pm 50$ b.c.

I $830 \pm 45$ a.d.

$1620 \pm 45$ a.d.

I $910 \pm 50$ a.d.

$1850 \pm 50$ a.d.

I $820 \pm 45$ a.d.

$5890 \pm 90$ b.c.

$3450 \pm 70$ b.c.

I $580 \pm 50$ a.d.

$2230 \pm 60$ b.c.

$4380 \pm 60$ b.c.

$3620 \pm 50$ b.c.

I $590 \pm 40$ a.d.

I $75 \pm 40$ a.d.

$5720 \pm 55$ b.c.

I $730 \pm 50$ b.c.

I $380 \pm 45$ a.d.

$50 \pm 50$ a.d.

$850 \pm 50$ a.d.

$455^{\circ} \pm 8$ o b.c.

$290 \pm 50$ b.c.

$4560 \pm 80$ b.c.

$640 \pm 60$ b.c.

$440 \pm 50$ b.c.

I $+0 \pm 50$ b.c.

$330 \pm 50$ a.d.

$1900 \pm 45$ a.d.

$1000 \pm+5$ a.d.

$825 \pm+5$ a.d.

$185 \pm 75$ a.d.

$+990 \pm 8$ o b.c.

$520 \pm 50$ a.d.

I $230 \pm+5$ a.d. 
Girls' School Shelter T6.4

Girls' School Shelter T6.2

Grillenberg charcoal

Conception midden

Enkwazini

Conception bone

Amis Schlucht pot

Fish River midden

Fish River burial

Apollo I I. VI 3

Haalenberg $\mathrm{P}_{3}$

Arrisdrift I

Arrisdrift pot

Gorob Mouth charcoal

Kumakams I . P2

Narob Grave

Hassenbild $\mathrm{T}_{2}$

Mpame

Unjab Midden

Haalenberg $\mathrm{P}_{2}$

Gorob Mouth log

Cha-re Shelter 2

Cha-re Shelter 3

Cha-re Shelter I

Arrisdrift ${ }_{5} \mathrm{~A}$

Limerock 2 Shelter

Orabes open site 02.I

Hungarob site $\mathrm{H}_{9}$

Ugab River site $\mathrm{BW} / \mathrm{I}$

Arrisdrift ${ }_{5} \mathrm{C}$

Wonderwerk Cave

Kumakams I . P I

Striped Giraffe Shelter

Aspoort Level 4

Aar I pot

Luderitz potsherd

Hottentot Bay pot

Nautilus pot

Rennydene (15)

Hudaob hut circles

Klein Africa

Klein Africa

Aspoort Level 2

Little Witkrans Shelter

Little Witkrans Shelter

Equus Cave

Sossusvlei I

Andriesgrond CAR 5/I

Andriesgrond $\mathrm{CAR}_{3 / 9}$ I

Andriesgrond CAR 5/2

Enkwazini

Little Witkrans Shelter

Maiphetwane

Mpambanyoni A5

Mpambanyoni B8

Doornkop

Doornkop
PTA I 776
P'TA I 777
P'TA I 832
PTA I 834
PTA I 848
P'TA I 863
PTA I 868
PTA I 895
PTA 1902
P'TA I 918
P'TA 1927
PTA 1933
P'TA 1945
P'TA 1988
PTA I 99 I
PTA 2006
PTA 2014
PTA 2017
PTA 2021
PTA 2650
PTA 2066
PTA 2075
PTA 2077
PTA 2082
PTA 2089
PTA 2095
PTA 2106
PTA 2107
PTA 2 I I I
PTA 2136
PTA 2140
PTA 2 I 43
PTA 2230
PTA 2250
PTA 2265
PTA 2264
PTA 2295
PTA 2296
PTA 2298
PTA 2361
PTA 2415
PTA 2420
PTA 2422
PTA 2447
PTA 2448
P'TA 2452
PTA 2470
PTA 2480
P'TA 248I
$830 \pm 60$ b.c.
$1040 \pm 40$ a.d.
$970 \pm 50$ a.d.
$1730 \pm 50$ a.d.
$1790 \pm 45$ a.d.
$1240 \pm 50$ a.d.
$1860 \pm 70$ a.d.
$1860 \pm 40$ a.d.
I $760 \pm 40$ a.d.
Io \pm 45 b.c.
$250 \pm 50$ b.c.
$750 \pm 50$ a.d.
$700 \pm 130$ a.d.
$740 \pm 40$ a.d.
I $900 \pm 45$ a.d.
$230 \pm 45$ a.d.
$1770 \pm 60$ a.d.
$1410 \pm 55$ a.d.
$740 \pm 60$ b.c.
$350 \pm 30$ b.c.
I $840 \pm 60$ b.c.
$3790 \pm 60$ b.c.
$4890 \pm 70$ b.c.
$1920 \pm 50$ a.d.
$650 \pm 50$ a.d.
$230 \pm 40$ a.d.
I $770 \pm 40$ a.d.
I $930 \pm 50$ a.d.
I $550 \pm 40$ a.d.
$670 \pm 40$ a.d.
$3980 \pm 50$ b.c.
I $920 \pm 35$ a.d.
I $580 \pm 40$ a.d.
$7470 \pm$ I 60 b.c.
I $870 \pm 45$ a.d.
I $650 \pm 50$ a.d.
$1460 \pm 50$ a.d.
I $550 \pm 50$ a.d.
$990 \pm 50$ a.d.
$1880 \pm 50$ a.d.
$1535 \pm 50$ a.d.
$1410 \pm 50$ a.d.
$4900 \pm 145$ b.c.
$460 \pm 40$ a.d.
$2760 \pm 65$ b.c.
$440 \pm 45$ b.c.
I $680 \pm 50$ a.d.
$310 \pm 50$ a.d.
$8050 \pm 90$ b.c.
$1520 \pm 50$ a.d.
I $650 \pm 50$ a.d.
P'TA 2485
PTA 2490
PTA 2526
PTA 2527
P'TA 2528
P'TA 2535
PTA 2536
$5520 \pm 90$ b.c.
$990 \pm 60$ a.d.
$970 \pm 50$ a.d.
$1020 \pm 50$ a.d.
I 2 I $0 \pm 50$ a.d.
I $140 \pm 50$ a.d. 
Enkwazini

Wonderwerk Cave

Wonderwerk Cave

Wonderwerk Cave

Wonderwerk Cave

Wonderwerk Cave

Wonderwerk Cave

Colwinton Rock Shelter

Colwinton Rock Shelter

Colwinton Rock Shelter

Warmquelle

Cape St Francis

Wortel WM I

Otjampaue furnace 2

Otjampaue furnace I

Arrisdrift $4 \mathrm{~A}$

Pearly Beach 2

Soetfontein

Friedenau slag

Colwinton Rock Shelter

Pearly Beach I

Pearly Beach 4

Pearly Beach 4

Pearly Beach 5

Pearly Beach 6

Numas Schlucht pot

Haalenberg $\mathrm{P}_{2}$

Zwei Schneider

Maguams

Aurus 6

Ururu

Messum I

Grassridge Rock Shelter

Grassridge Rock Shelter

Wonderwerk Cave

Wonderwerk Cave

Wonderwerk Cave

Wonderwerk Cave

Wonderwerk Cave

Wonderwerk Cave

Wonderwerk Cave

Wonderwerk Cave

Wonderwerk Cave

Umbeli Belli

Umbeli Belli

Blinkklipkop

Blinkklipkop

Blinkklipkop

Blinkklipkop

Blinkklipkop

Rooiberg U4

Rooiberg U4

Rooiberg U3

Rooiberg U4

Wonderwerk Cave

Byneskranskop

Byneskranskop
PTA 2537

PTA 254I

P'TA 2542

P'TA 2543

P'TA 2544

PTA 2455

P'TA 2546

PTA 2547

PTA 2549

PTA 2550

PTA 2552

PTA 2553

PTA 2554

PTA 2559

PTA 2564

PTA 2565

P'TA 2567

PTA 2568

PTA 2573

PTA 2608

PTA 2620

PTA 262 I

PTA 2622

PTA 2626

PTA 263I

PTA 2645

PTA $265^{\circ}$

P'TA 2654

PTA 2662

PTA 2663

PTA 2664

PTA 268I

PTA 27I 3

PTA 2719

PTA 2723

P'TA 2727

PTA 2728

PTA 2729

P'TA 2779

PTA 2785

PTA 2790

PTA 2797

P'TA 2798

P'TA 2824

PTA 2825

PTA 2833

PTA 2835

PTA 2839

PTA 2840

PTA 284I

P'TA 2845

P'TA 2847

PTA 2849

P'TA 2850

P'TA 2852

PTA 2855

P'TA 2869
$1860 \pm 50$ a.d.

$2290 \pm 60$ b.c.

$60 \pm 50$ a.d.

$960 \pm 60$ b.c.

$3230 \pm 70$ b.c.

$4020 \pm 70$ b.c.

$7180 \pm 90$ b.c.

I $880 \pm 40$ a.d.

$60 \pm 45$ a.d.

$720 \pm 40$ b.c.

$190 \pm 50$ b.c.

$800 \pm 40$ a.d.

I $580 \pm 30$ a.d.

I $670 \pm 40$ a.d.

$1820 \pm 50$ a.d.

$360 \pm 50$ a.d.

$500 \pm 50$ a.d.

$920 \pm 50$ b.c.

I $530 \pm 50$ a.d.

$1030 \pm 50$ a.d.

ro80 \pm 50 a.d.

$255 \pm 45$ a.d.

$245 \pm 60$ a.d.

I $560 \pm 40$ a.d.

I $35 \pm 50$ a.d.

I $530 \pm$ I 40 a.d.

$350 \pm 50$ b.c.

$3900 \pm 70$ b.c.

I $570 \pm 50$ a.d.

$790 \pm 50$ a.d.

$950 \pm 60$ a.d.

$580 \pm 50$ a.d.

$4330 \pm 70$ b.c.

$4940 \pm 80$ b.c.

$400 \pm 50$ b.c.

$310 \pm 60$ b.c.

I $410 \pm 60$ b.c.

$980 \pm 60$ b.c.

$740 \pm 50$ a.d.

$2040 \pm 60$ b.c.

$950 \pm 70$ a.d.

$2940 \pm 70$ b.c.

$5480 \pm 60$ b.c.

I $750 \pm 50$ a.d.

$8 \mathrm{ro} \pm 50$ a.d.

I $690 \pm 45$ a.d.

$800 \pm 40$ a.d.

I $670 \pm 50$ a.d.

$790 \pm 50$ a.d.

$1870 \pm 35$ a.d.

$280 \pm 50$ a.d.

3 Io \pm 40 a.d.

$370 \pm 30$ a.d.

I $90 \pm 30$ a.d.

$7810 \pm$ I 20 b.c.

$470 \pm 50$ b.c.

$830 \pm 50$ b.c. 
Grassridge Rock Shelter

Grassridge Rock Shelter

Byneskranskop

Grassridge Rock Shelter

Clarke's Shelter

Clarke's Shelter

Diamond I

Diamond 1

Douglas

Doornfontein

Khartoum I

Kimberley

Borcher's Shelter

Borcher's Shelter

Waterval West 3

Borcher's Shelter

I ambert's Bay shell

Gehle Shelter

Gehle Shelter

Gehle Shelter

Diamond

Clarke's Shelter

Mhlanga Lagoon

Nkupe Shelter

Nkupe Shelter

Nkupe Shelter

Norfolk Road

Nali Hill

Nali Hill

Nali Hill

Nali Hill

Mwala Hill

Mwala Hill

Mwala Hill

Tortoise Cave

Tortoise Cave

Tortoise Cave

Tortoise Cave

Kreefbaai C6/A

Kreefbaai C6/F

Suurwater

Bitterputs I

Norlim 5

Zaayfontein Shelter

Glen Elliott Shelter

Dikbosch I

Dikbosch I

Dikbosch I

Biessiesfontein

Blinkklipkop

Norlim 5

Nkupe Shelter

Dithakong I

Nkupe Shelter

Heuningvlei 2

Nkupe Shelter

Kasteelberg A

\begin{tabular}{|c|c|}
\hline PTA 2949 & $4900 \pm 100$ b.c \\
\hline P'A $295^{2}$ & $4350 \pm 50$ b.c. \\
\hline PTA 2969 & I $960 \pm 50$ b.c. \\
\hline PTA 2970 & $4 \mathrm{I} 40 \pm 80$ b.c. \\
\hline P'TA 297 I & $210 \pm 50$ b.c. \\
\hline P'ГA 2973 & $370 \pm 50$ a.d. \\
\hline P'TA 2974 & $1070 \pm 60$ b.c. \\
\hline P'TA 2977 & $860 \pm 60$ b.c. \\
\hline P'TA 3088 & I $540 \pm 50$ a.d. \\
\hline P'TA 3089 & I $820 \pm 80$ a.d. \\
\hline PTA 3093 & I $380 \pm 60$ a.d. \\
\hline P'TA 3094 & I $740 \pm 45$ a.d. \\
\hline PTA 3107 & I $850 \pm 50$ a.d. \\
\hline PTA 3108 & $120 \pm 50$ b.c. \\
\hline PTA 3109 & I $600 \pm 45$ a.d. \\
\hline P'TA 3 I 10 & $1410 \pm$ \\
\hline PTA 3201 & I $220 \pm 60$ b.c. \\
\hline P'TA 3242 & $670 \pm 50$ a.d. \\
\hline PTA 3243 & I $200 \pm 50$ a.d. \\
\hline PTA 3245 & $2380 \pm 50$ b.c. \\
\hline PTA 3246 & $2950 \pm 60$ b.c. \\
\hline PTA 3247 & $430 \pm 50$ b.c. \\
\hline $\mathrm{P}^{\prime} \mathrm{TA} 3268$ & $870 \pm 70$ a.d. \\
\hline PTA 3269 & I $240 \pm 60$ b.c. \\
\hline PTA 3275 & o b.c. \\
\hline P'TA 3276 & $2640 \pm 70$ b.c. \\
\hline $\mathrm{P}^{\prime}$ ГА 3299 & $770 \pm 5$ \\
\hline P'TA 3300 & $1000 \pm 50$ a.d. \\
\hline P'TA 3301 & $980 \pm 5$ \\
\hline $\mathrm{P}^{\prime} \mathrm{TA} 3302$ & I $100 \pm 50$ a.d. \\
\hline РТА 3304 & $890 \pm 5$ \\
\hline PTA 3305 & $870 \pm 50$ a.d. \\
\hline P'TA 3307 & $850 \pm 50$ a.d. \\
\hline P'TA 3308 & $880 \pm 50$ a.d. \\
\hline PTA 3309 & $370 \pm 50$ a.d. \\
\hline PTA 3310 & $330 \pm 50$ a.d. \\
\hline PTA 33 I I & $340 \pm 50$ a.d. \\
\hline P'TA 3312 & $270 \pm 50$ a.d. \\
\hline A 33 I3 & I $520 \pm 60$ b.c. \\
\hline PTA 3314 & $510 \pm 60$ b.c. \\
\hline PTA 3357 & $840 \pm 45$ a.d. \\
\hline PTA 3359 & $1460 \pm 40$ a.d. \\
\hline PTA 3367 & I $550 \pm 40$ a.d. \\
\hline PTA 3392 & $1650 \pm 50$ a.d. \\
\hline PTA 3401 & I $430 \pm 90$ a.d. \\
\hline PTA 34 I I & $6060 \pm 60$ b.c. \\
\hline PTA 34 I 2 & $380 \pm 40$ a.d. \\
\hline $\mathrm{P}^{\prime} \mathrm{TA} 34 \mathrm{I} 3$ & $230 \pm 40$ a.d. \\
\hline PrIA 34 I 7 & I $510 \pm 40$ a.d. \\
\hline PTA 34 I9 & I $20 \pm 45$ a.d. \\
\hline PTA 3421 & I $560 \pm 40$ a.d. \\
\hline P'TA 3443 & $530 \pm 60$ b.c. \\
\hline PTA 3444 & I $840 \pm 60$ a.d. \\
\hline PTA 3455 & $4700 \pm 80$ b.c. \\
\hline PTA 3458 & \\
\hline 3460 & I 3 \\
\hline PTA 3461 & . \\
\hline
\end{tabular}


Dithakong I

Dithakong I

Pomfret I

Bethelsklip

Kreefbaai C6/B

Tortoise Cave

Tortoise Cave

Tortoise Cave

Tortoise Cave

Tortoise Cave

Tortoise Cave

Mussel Point E $4 / 3$

Mussel Point $\mathrm{E}_{3 / 2}$

Mussel Point E $4 / 7$

Kasteelberg A

Kasteelberg B

Kasteelberg B

Kasteelberg B

Renbaan

Renbaan

Renbaan

Kasteelberg C

Kasteelberg B

Kasteelberg C

Kasteelberg B

Kasteelberg B

Wonderwerk Cave

Xgi

Xgi

Xgi

Matola

Matola

Matola

Caimane

Caimane

Eiland Saltworks

Eiland Saltworks

Outpost I

Broadhurst

Bambo

Bisoli

Simawe

Dombashaba Ruin
PTA 3462

PTA 3466

PTA 3488

PTA 35 I 2

PTA 3589

PTA 3595

PTA 3596

PTA 3600

PTA 3604

PTA 3605

PTA 3608

PTA 3640

PTA $364 \mathrm{I}$

PTA 3659

PTA 37 I I

PTA 3737

PTA 3742

PTA 3747

PTA 3766

PTA 3768

PTA 3783

PTA 3785

PTA 3787

P'TA 3788

PTA 3994

PTA 3995

SI 2030

SI 409 I A

SI 409 I C

SI 4098

ST 8546

ST 8547

ST 8548

ST 8879

ST 8880

Wits 762

Wits 764

Wits 836

Wits 837

Wits 935

Wits 1099

Wits I 2 IO

Wits I 2 I 6
$1720 \pm 40$ a.d.

$1730 \pm 40$ a.d.

I $630 \pm 50$ a.d.

I I $50 \pm 50$ a.d.

$540 \pm 60$ b.c.

$2070 \pm 60$ b.c.

6 I $50 \pm 70$ b.c.

I I $90 \pm 50$ a.d.

I $570 \pm 60$ b.c.

$2380 \pm 50$ b.c.

$2240 \pm 60$ b.c.

I $70 \pm 60$ a.d.

I $80 \pm 50$ b.c.

$140 \pm 50$ b.c.

$90 \pm 60$ a.d.

I $760 \pm 40$ a.d.

$1030 \pm 40$ a.d.

$1070 \pm 50$ a.d.

$2480 \pm 70$ b.c.

$800 \pm 50$ a.d.

$40 \pm 60$ a.d.

$680 \pm 50$ a.d.

r $040 \pm 50$ a.d.

$210 \pm 50$ b.c.

$780 \pm 45$ a.d.

$690 \pm 60$ a.d.

$4050 \pm 55$ b.c.

I $455 \pm 45$ a.d.

I I $40 \pm 60$ a.d.

I $840 \pm 50$ a.d.

$230 \pm$ i ro a.d.

$480 \pm 80$ a.d.

$75 \pm 80$ b.c.

$6095 \pm$ i ro b.c.

$6060 \pm$ i ro b.c.

$330 \pm 50$ a.d.

$1460 \pm 40$ a.d.

$980 \pm 50$ a.d.

$1360 \pm 60$ a.d.

I $720 \pm 60$ a.d.

$610 \pm 50$ a.d.

I I IO \pm 70 a.d.

$490 \pm 50$ a.d. 